Ireneusz KRAŚ

Akademia im. Jana Długosza, Częstochowa

\title{
POLITYKA BANKU CENTRALNEGO A BEZPIECZEŃSTWO FINANSOWE PAŃSTWA
}

Bezpieczeństwo to przedmiot zainteresowań politologii, ekonomii, prawa, socjologii, historii, nauki o stosunkach międzynarodowych. Termin „bezpieczeństwo” wywodzi się od łacińskiego słowa sine cura i oznacza w potocznym rozumieniu brak zagrożenia oraz ochronę przed zagrożeniem. W starożytnym Rzymie oznaczał on polityczną stabilność. Pojęcie bezpieczeństwa pojmowane jest jako stan spokoju, pewności zabezpieczenia i jego poczucia ${ }^{1}$. Bezpieczeństwo w ujęciu ogólnym to pewność istnienia i przetrwania, posiadania oraz funkcjonowania i rozwoju podmiotu. Jest wynikiem braku zagrożeń i właściwej ich percepcji, powstaje też wskutek kreatywnej działalności podmiotu. Jest procesem społecznie zmiennym w czasie ${ }^{2}$.

Bezpieczeństwo wewnętrzne to stan polityczno-administracyjny państwa, który gwarantuje jego obywatelom brak zagrożenia dla jego funkcjonowania, zapewnia spokój, poszanowanie porządku publicznego, jak również interesu publicznego, ochronę społeczności i każdego obywatela. Bezpieczeństwo wewnętrzne związane jest z realizacją zadań powierzonych administracji poszczególnych resortów i instytucji bezpieczeństwa wewnętrznego. Realizowane ono jest w postaci akcji, przymusu, działań, prewencji, analizy i zbierania danych oraz informacji niejawnych dających podstawę do ochrony bezpieczeństwa państwa, obywatela i porządku publicznego ${ }^{3}$.

Bezpieczeństwo państwa to zdolność władz i narodu do ochrony jego wewnętrznych wartości. Można je rozpatrywać z punktu widzenia trzech kryteriów. Pierwszym jest kryterium podmiotowe, wskazujące o czyje bezpieczeństwo chodzi. Drugim - kryterium przedmiotowe, określające co jest treścią bezpieczeństwa. Kryterium trzecie ma charakter funkcjonalny i pozwala na obserwację zmienności w czasie subiektywnych i obiektywnych aspektów bezpieczeństwa.

\section{SIEĆ BEZPIECZEŃSTWA FINANSOWEGO PAŃSTWA}

Jednym z elementów bezpieczeństwa rozpatrywanego z przedmiotowego punktu widzenia jest bezpieczeństwo ekonomiczne, funkcjonujące jako bezpieczeństwo finansowe, surowcowe, technologiczne, żywnościowe, rolne ${ }^{4}$.

1 R. Zięba, Instytucjonalizacja bezpieczeństwa europejskiego: koncepcje - struktury - funkcjonowanie, Warszawa 2004, s. 27.

2 J.Zając, Bezpieczeństwo państwa, w: Bezpieczeństwo państwa. Wybrane problemy, red. K. A. Wojtaszczyk, A. Materska-Sosnowska, Warszawa 2009, s. 18.

3 M. Świderski, Bezpieczeństwo wewnętrzne i jego uwarunkowania, w: Bezpieczeństwo państwa. Wybrane problemy, op. cit., s. 58-59.

4 J. Zając, Bezpieczeństwo państwa, op. cit., s. 18-19. 
XXI wiek rewolucyjnie zmienia problematykę bezpieczeństwa państwa. Zwiększa się liczba wyzwań i podmiotów biorących udział w różnorodnych przedsięwzięciach i oczekiwaniach na ochronę swoich wartości ${ }^{5}$. Coraz większą rolę zaczyna odgrywać bezpieczeństwo finansowe państwa, a w szczególności podmioty je tworzące.

Pojęcie bezpieczeństwa finansowego nie zostało jeszcze dokładnie zdefiniowane. Jest ono elementem bezpieczeństwa ekonomicznego państwa. Zakłócenia na rynkach finansowych powodują sytuację, w której źle zaczyna funkcjonować cała gospodarka, stanowiąc tym samym największe zagrożenie dla bezpieczeństwa ekonomicznego państwa ${ }^{6}$. M. Iwanicz-Drozdowska definiuje bezpieczeństwo finansowe jako ogół regulacji prawnych oraz samoregulacji mających na celu zapewnienie stabilności finansowej oraz ochronę interesów uczestników rynku korzystających z usług pośredników finansowych, a także ogół instytucji odpowiadających za kontrolę przestrzegania tych regulacji i samoregulacji ${ }^{7}$. Definicja bezpieczeństwa finansowego prezentowana przez R. Wierzbę to zespół rozwiązań instytucjonalnych i regulacji prawnych, mających na celu ochronę sytemu finansowego przed destabilizacją ${ }^{8}$.

Czynniki wewnętrzne warunkujące bezpieczeństwo finansowe odnoszą się do poszczególnych „wymiarów” bezpieczeństwa finansowego, zaś czynniki zewnętrzne, to szeroko rozumiane otoczenie, w którym rolę szczególną spełnia sieć bezpieczeństwa finansowego państwa (ang. safety net).

Do podstawowych czynników wewnętrznych bezpieczeństwa finansowego zalicza się:

- bezpieczeństwo instytucji finansowych (kondycja ekonomiczno-finansowa, system zarządzania ryzykiem);

- bezpieczeństwo transakcji finansowych (wiarygodność finansowa kontrahenta, przedmiot transakcji, system rozliczeń);

- bezpieczeństwo segmentów rynku finansowego (mechanizm funkcjonowania danego rynku, zachowania uczestników);

- bezpieczeństwo klienta rynku finansowego (asymetria informacji, system ochrony).

Wszystkie wymienione czynniki bezpieczeństwa finansowego są ze sobą powiązane na zasadzie sprzężenia zwrotnego'.

Determinanty zewnętrzne bezpieczeństwa finansowego to przede wszystkim sieć bezpieczeństwa finansowego państwa, którą tworzą następujące podmioty:

- rządy (reprezentowane przez ministra finansów);

- banki centralne;

${ }^{5}$ K. A. Wojtaszczyk, Bezpieczeństwo państwa - konceptualizacja pojęć, w: Bezpieczeństwo państwa. Wybrane problemy, op. cit., s. 16.

6 A. Jurkowska-Zejdler, Bezpieczeństwo rynku finansowego w świetle prawa Unii Europejskiej, Warszawa 2008, s. 167.

${ }^{7}$ M. Iwanicz-Drozdowska, Bezpieczeństwo rynku uslug finansowych. Perspektywa Unii Europejskiej, Warszawa 2008, s. 22.

${ }^{8}$ R. Wierzba, System gwarantowania depozytów jako element sieci bezpieczeństwa finansowego. Doświadczenia francuskie, „Bezpieczny Bank” 2005, nr 1, s. 38.

9 M. Capiga, Determinanty i struktura bezpieczeństwa finansowego, w: Sieć bezpieczeństwa finansowego, red. M. Capiga, W. Gradoń, G. Szustak, Warszawa 2010, s. 12. 
- instytucje nadzoru finansowego;

- systemy gwarantowania depozytów ${ }^{10}$.

Należy zaznaczyć, że sieć bezpieczeństwa finansowego państwa obejmuje nie tylko instytucje publiczne, lecz również podmioty prywatne ${ }^{11}$. Pełną sieć bezpieczeństwa finansowego państwa budują więc instytucje publiczne i instytucje prywatne.

Przez sieć bezpieczeństwa finansowego państwa należy zatem rozumieć zespół rozwiązań instytucjonalnych i regulacji prawnych, mających na celu ochronę systemu finansowego przed destabilizacją ${ }^{12}$. Szeroką definicję sieci bezpieczeństwa finansowego państwa od strony instytucjonalnej prezentuje M. Iwanowicz-Drozdowska wskazując, że „,sieć bezpieczeństwa finansowego obejmuje w szczególności instytucję bądź instytucje nadzoru, instytucję bądź instytucje zapewniające ochronę antyupadłościową klientom pośredników finansowych (systemy gwarantowania depozytów, systemy rekompensat dla inwestorów, ubezpieczeniowe fundusze gwarancyjne), bank centralny jako podmiot dostarczający płynności na rynek (wypłacalnym bankom) oraz ministerstwo finansów (bądź skarbu) jako potencjalnego pożyczkodawcę dla niewypłacalnych banków i dysponenta środków na potencjalną restrukturyzację instytucji finansowych. Ponadto, do sieci bezpieczeństwa finansowego w szerokim rozumieniu należy zaliczyć izby gospodarcze odpowiedzialne za tworzenie i kontrolę przestrzegania samoregulacji, a także instytucje zapewniające dopływ odpowiednich informacji do instytucji finansowych np. biura informacji kredytowej”,13.

Celem sieci bezpieczeństwa finansowego państwa jest zapewnienie stabilności systemu finansowego. Stabilność finansowa według Narodowego Banku Polskiego rozumiana ,jest jako stan, w którym system finansowy pełni swoje funkcje w sposób ciagły i efektywny, nawet w przypadku wystapienia nieoczekiwanych i niekorzystnych zaburzeń o znacznej skali. Zakłócenia w pracy systemu finansowego i zaburzenia efektywności świadczenia usług pośrednictwa finansowego negatywnie wpływają na sytuację przedsiębiorstw i gospodarstw domowych"14. Zapewnienie stabilności finansowej państwa jest procesem ciagłym i najczęściej przebiega w dwóch etapach. Etap pierwszy polega na zapobieganiu kryzysom, w którym wprowadza się rozwiązania regulacyjne i instytucjonalne określające podstawowe reguły gry rynkowej, które chronią podmioty gospodarcze przed zbytnim ryzykiem, w ramach tego etapu podejmuje się również działania polegające na monitoringu i identyfikacji potencjalnych zagrożeń,

${ }^{10}$ O. Szczepańska, Stabilność finansowa jako cel banku centralnego. Studium teoretyczno-porównawcze, Scholar, Warszawa 2008, s. 50.

$11 \mathrm{~W}$ przypadku podmiotów prywatnych chodzi o rozwiązania rynkowe, polegające na wypracowaniu przez sektor prywatny różnych mechanizmów zabezpieczających, które służą wzmocnieniu dyscypliny rynkowej i mają na celu ograniczenie ryzyka w systemie finansowym lub rozwiązywanie kryzysu bez angażowania podmiotów publicznych np. prywatne fundusze gwarantowania depozytów lub prywatne limity wyznaczone przez poszczególne banki na kwoty pożyczek międzybankowych.

O. Szczepańska, P. Sotomska-Krzysztofik, M. Pawliszym, A. Pawlikowski, Instytucjonalne uwarunkowania stabilności finansowej, na przykładzie wybranych krajów, NBP, „Materiały i Studia” 2004, nr 173, s. 8-9, http://www.nbp.pl/publikacje/materialy_i_studia/ms173.pdf (11.08.2011).

${ }_{13}$ M. Iwanowicz-Drozdowska, Bezpieczeństwo rynku ustug finansowych. Perspektywa Unii Europejskiej, op. cit., s. 23.

${ }_{14}$ Cyt. za: Raport o stabilności systemu finansowego, Warszawa 2012, http://www.nbp.pl/ home.aspx?f=/systemfinansowy/stabilnosc.html (21.02.2013). 
po to aby zapobiec ich nasilaniu w przyszłości. Drugi etap to zarządzanie i rozwiązywanie kryzysu polegające na działaniach zmierzających do ograniczenia skutków i kosztów kryzysu ${ }^{15}$.

Podstawowymi przesłankami dla sieci bezpieczeństwa finansowego państwa w przypadku zapewnienia stabilności systemu finansowego są:

- stabilność finansowa uznawana za dobro publiczne;

- niedoskonałości rynku finansowego, które zakłócająjego sprawne funkcjonowanie;

- asymetria informacji przejawiająca się w nierównym dostępie do informacji o uczestnikach transakcji finansowych, jako podstawy podejmowania decyzji finansowych;

- ryzyko systemowe ${ }^{16}$.

\section{BANK CENTRALNY JAKO PODSTAWOWY ELEMENT SIECI BEZPIECZEŃSTWA FINANSOWEGO}

Od czasów starożytnych po współczesność rynki finansowe doznały wielu wstrząów. W związku z tym inwestorzy tracili ulokowane środki. Przyczyną takiego stanu rzeczy był brak uporządkowania zasad emisji pieniądza oraz brak zasad dopuszczenia pośredników finansowych na rynek. Spośród podmiotów wchodzących w skład sieci bezpieczeństwa finansowego państwa problemami, które powodowały wstrząsy jako pierwsze zajęły się banki centralne. Mają one najdłuższą historię działania na rzecz stabilności finansowej państwa.

W dyskusji nad stabilizacją systemu finansowego przez banki centralne w ramach sieci bezpieczeństwa finansowego państwa przedstawiane są różne argumenty. Można je podzielić na dwie grupy: argumenty „za” i ,przeciw” stabilizacji systemu finansowego. Do grupy argumentów za stabilizowaniem systemu finansowego przez bank centralny zaliczamy:

- w zakresie realizacji podstawowego celu banku centralnego stabilność systemu finansowego jest warunkiem powodzenia działań banku centralnego w zakresie polityki pieniężnej;

- bank centralny jest jedyną instytucją mogącą dostarczyć prawny środek płatniczy dla gospodarki w terminach i kwotach niezbędnych w sytuacji kryzysowej;

- pierwotnym celem banku centralnego była dbałość o stabilne i płynne funkcjonowanie systemu finansowego i płatniczego;

- bank centralny jest odpowiedzialny za sprawne i płynne funkcjonowanie systemu płatniczego i rozliczeniowego;

- jeden ośrodek decyzyjny i brak procedury parlamentarnej zwiększają skuteczność działań stabilizacyjnych;

15 O. Szczepańska, Stabilność finansowa jako cel banku centralnego. Studium teoretyczno-porównawcze, op. cit., s. 51.

${ }^{16}$ O. Szczepańska, Podstawowe przesłanki, założenia i struktura sieci bezpieczeństwa finansowego $w$ świetle teorii i doświadczeń międzynarodowych, „Bezpieczny Bank” 2005, nr 1, s. 20-22, http://www.bfg.pl/doc_media/wezel_871/026.pdf (16.08.2012). 
- krótkie opóźnienia wewnętrzne polityki sprzyjają terminowemu podejmowaniu niezbędnych działań stabilizacyjnych ${ }^{17}$.

W dyskusji dotyczącej stabilizacji systemu finansowego państwa przez bank centralny prezentowane są również argumenty „przeciw”. Wśród nich możemy wyróżnić następujące argumenty:

- stabilizowanie systemu finansowego przez bank centralny jest zagrożeniem dla realizacji podstawowego celu banku centralnego;

- utrudnienia w uzyskaniu społecznej akceptacji dla działań banku centralnego;

- realizacja funkcji banku centralnego powinna być podporządkowana wyłącznie osiągnięciu jego celu podstawowego;

- rozszerzenie celów banku centralnego nie jest związane ze wzrostem liczby narzędzi;

- w przypadku uznania stabilności finansowej za cel banku centralnego należy przyporządkować określone narzędzia realizacji tego celu;

- stabilność systemu finansowego nie spełnia podstawowych warunków, jakie powinien spełniać cel banku centralnego ${ }^{18}$.

\section{STABILNOŚĆ FINANSOWA A STABILNOŚĆ MONETARNA}

Ustawodawstwo poszczególnych państw unijnych nie zawsze jednak narzuca wprost bankom centralnym obowiązek zapewnienia stabilności systemu finansowego. Przegląd aktów prawnych regulujących działalność banków centralnych wskazuje na to, że odniesienia do stabilności finansowej w ustawach o bankach centralnych nie są regułą $^{19}$. Wspieranie stabilności finansowej nie jest również formalnie zapisanym prawnie zadaniem Europejskiego Banku Centralnego. EBC podobnie jak Narodowy Bank Polski dba przede wszystkim o stabilność cen na obszarze strefy euro. Taka sytuacja związana jest z konfliktem interesów występującym w relacji: stabilność finansowa - stabilność cen. Wspieranie przez bank centralny stabilności finansowej jest związane z przejęciem przez niego części funkcji nadzorczych nad systemem bankowym, a cele nadzoru i cele polityki monetarnej mogą być sprzeczne ${ }^{20}$.

$\mathrm{Z}$ formalnego punktu widzenia stabilność finansowa ma niższy priorytet niż cel monetarny (pieniężny). W praktyce jednak banki centralne nie kwestionują swojego zaangażowania $\mathrm{w}$ zapewnieniu stabilności systemowi finansowemu $\mathrm{w}$ ramach sieci bezpieczeństwa finansowego państwa. Główne uzasadnieniem, na jakie powołują się banki centralne w tej kwestii, to związek stabilności finansowej ze stabilnością cen, która jest statutowym celem wszystkich banków centralnych. Zależność między tymi dwoma celami jest obustronna. Sprawność systemu finansowego wpływa na warunki realizacji polityki pieniężnej, natomiast skuteczność polityki monetarnej ma wpływ na

17 A. Matysek-Jędrych, Rola banków centralnych w działaniach na rzecz stabilności finansowej. Częśśc I, „Bank i Kredyt”, Część edukacyjna 2011, nr 3, s. 6.

18 Ibidem.

19 O. Szczepańska, Stabilność finansowa jako cel banku centralnego. Studium teoretyczno-porównawcze, op. cit., s. 67.

${ }^{20}$ G. Szustak, Bank centralny jako ogniwo sieci bezpieczeństwa finansowego, w: Sieć bezpieczeństwa finansowego, op. cit., s. 54. 
kształtowanie się sytuacji w tym systemie. Opisana relacja sprawia, że banki centralne w pierwszym rzędzie odpowiedzialne formalnie za stabilność cen, są zainteresowane sprawnym działaniem systemu finansowego.

W dyskusji na temat związku stabilności finansowej ze stabilnością monetarną możemy wyróżnić dwa nurty:

- nurt konwencjonalny (tradycyjny);

- nurt określany new environment.

Przedstawiciele nurtu konwencjonalnego uznają że stabilność finansowa i stabilność cen są komplementarnymi celami banków centralnych. Wysoka inflacja to jeden z najważniejszych czynników prowadzących do niestabilności finansowej. W przypadku deflacji (ujemna inflacja) zmniejsza się alternatywny koszt utrzymania gotówki, co może spowodować wycofanie wkładów z banków, zmianami struktury ich pasywów w kierunku bardziej płynnych i w konsekwencji redukcją zysków banków. Jednak większość ekonomistów reprezentujących nurt tradycyjny uważa, ze stabilność cen jest warunkiem, który sprzyja stabilności finansowej, ale jej nie gwarantuje. Z kolei przedstawiciele nurtu new environment twierdza, że utrzymująca się przez długi czas stabilna i niska inflacja może tworzyć sprzyjające warunki do dynamicznego wzrostu cen aktywów. Zjawisko to nosi nazwę bąbli spekulacyjnych ${ }^{21}$.

W Unii Gospodarczej i Walutowej sześć banków na siedemnaście ma prawny obowiązek zapewnienia stabilności systemu finansowego. Grupę tą tworzą: Bank Belgii, Finlandii, Hiszpanii, Holandii, Irlandii i Portugalii. Natomiast poza strefą euro obowiązek prawny zapewnienia stabilności systemu finansowego mają Bank Anglii i Narodowy Bank Wegier ${ }^{22}$.

Ustawa o Narodowym Banku Polskim nie zawiera zapisu mówiącego, że podstawowym celem działalności jest zapewnienie stabilności systemu finansowego. Podstawowym celem banku centralnego w Polsce zgodnie z art. 3 ust. 1 ustawy o NBP jest utrzymanie stabilnego poziomu cen, przy jednoczesnym wspieraniu polityki gospodarczej Rządu, o ile nie ogranicza to podstawowego celu NBP ${ }^{23}$. Niemniej jednak w tym samym artykule ust. 2 pkt 5, 6 i 6 a wskazano, że do zadań NBP należy regulowanie płynności banków, ich refinansowanie, kształtowanie warunków niezbędnych do rozwoju systemu bankowego oraz działania na rzecz stabilności krajowego systemu finansowego ${ }^{24}$. Natomiast do zadań Zarządu NBP zgodnie z art. 17, ust. 4 pkt 5 i 5 a ustawy o NBP należy ocena funkcjonowania systemu bankowego i analiza stabilności krajowego systemu finansowego ${ }^{25}$.

W pracach na rzecz stabilności krajowego systemu finansowego bierze udział Prezes NBP. Jest on członkiem Komitetu Stabilności Finansowej. Na podstawie ustawy o Komitecie Stabilności Finansowej zgodnie z art. 4 ust. 1 członkami komitetu są Minister Finansów, Prezes Narodowego Banku Polskiego i Przewodniczący Komisji Nad-

\footnotetext{
21 O. Szczepańska, Stabilność finansowa jako cel banku centralnego. Studium teoretyczno-porównawcze, op. cit., s. 76-88.

22 G. Szustak, Bank centralny jako ogniwo sieci bezpieczeństwa finansowego, w: Sieć bezpieczeństwa finansowego, op. cit., s. 54.

${ }_{23}$ Art. 3(1), Ustawa z 29 sierpnia 1997 r. o Narodowym Banku Polskim, Dz. U. 2005, Nr 1, poz. 2.

24 Art. 3(2), Ustawa z 29 sierpnia 1997 r. o Narodowym Banku Polskim, op. cit.

25 Art. 17(4), Ustawa z 29 sierpnia 1997 r. o Narodowym Banku Polskim, op. cit.
} 
zoru Finansowego ${ }^{26}$. Celem działania komitetu zgodnie z art. 1 ust. 2 jest zapewnienie efektywnej współpracy w zakresie wspierania i utrzymania stabilności krajowego systemu finansowego poprzez wymianę informacji, opinii i ocen sytuacji w systemie finansowym w kraju i za granicą oraz koordynacji działań w tym zakresie ${ }^{27}$.

Zgodnie z art. 3 ust. 1 ustawy o Komitecie Stabilności Finansowej Prezes NBP powinien:

1) dokonywać ocen sytuacji w krajowym systemie finansowym i na rynkach międzynarodowych oraz zapewnić właściwy obieg informacji pomiędzy członkami Komitetu dotyczących istotnych zdarzeń i tendencji mogących stanowić zagrożenie dla stabilności krajowego systemu finansowego;

2) opracowywać i przyjmować procedury współdziałania na wypadek wystapienia zagrożenia dla stabilności krajowego systemu finansowego;

3) koordynować działania członków Komitetu w sytuacji bezpośredniego zagrożenia dla stabilności krajowego systemu finansowego ${ }^{28}$.

Ponadto Narodowy Bank Polski zgodnie z art. 42 ust. 1 ustawy o NBP może udzielać bankom kredytu refinansowego ${ }^{29}$ w złotych w celu uzupełnienia ich zasobów pieniężnych. Natomiast art. 44 ust. 1 ustawy o NBP daje Narodowemu Bankowi Polskiemu możliwość przyjmowania od banków weksli do dyskonta i redyskonta ${ }^{30}$.

Bank centralny Szwecji (Riksbank) zgodnie z ustawą dba o stabilność cen. Jednak w ustawie jest artykuł dotyczący zapewnienia bezpiecznego i skutecznego systemu rozliczeń. Według oficjalnej interpretacji Banku Szwecji, funkcja wspierania bezpieczeństwa i efektywności systemu płatniczego powinna być pojmowana szerzej - jako zadanie wspierania stabilności całego systemu finansowego ${ }^{31}$. W związku z tym dokonuje on ogólnej oceny i kontroli stabilności systemu finansowego. Ma on prawo, w wyjątkowych okolicznościach, dostarczenia płynności instytucjom finansowym nadzorowanym przez FSA ${ }^{32}$. Ponadto instytucje kredytowe lub inne instytucje nadzorowane przez FSA zobowiązane są dostarczyć Bankowi Szwecji niezbędne informacje, które wykorzystuje on do zapewnienia stabilności systemu płatniczego ${ }^{33}$.

26 Art. 4(1), Ustawa z 7 listopada 2008 r. o Komitecie Stabilności Finansowej, Dz. U. 2008, Nr 209, poz. 1317.

27 Art. 1(2), Ustawa z 7 listopada 2008 r. o Komitecie Stabilności Finansowej, op. cit.

28 Art. 3(1), Ustawa z 7 listopada 2008 r. o Komitecie Stabilności Finansowej, op. cit.

29 Kredyt refinansowy to jeden $\mathrm{z}$ instrumentów polityki pieniężnej, który pozwala bankom komercyjnym na finansowanie ich działalności w drodze refinansowania się w banku centralnym. Pełni on wiele funkcji w systemie finansowym państwa. Najważniejsze z nich to: refinansowanie operacji aktywnych banków komercyjnych; wpływ na rynkową stopę procentową; pomoc w odzyskiwaniu płynności banku komercyjnego w sytuacjach nagłego jej zachwiania; usprawnianie systemu rozliczeń pieniężnych; stabilizowanie od góry zmienności rynkowych stóp procentowych; wpływ na rozwój rynków poszczególnych papierów wartościowych.

${ }^{30}$ Ustawa z 29 sierpnia 1997 r. o Narodowym Banku Polskim, Dz. U. z 2005, Nr 1, poz. 2.

31 P. Sotomska-Krzysztofik, Jak Bank Szwecji wspiera stabilność finansowq za pomoca polityki informacyjnej, „Bank i Kredyt” 2005, nr 1, s. 17.

32 Instytucja nadzorująca system finansowy w Szwecji.

33 A. Matysek-Jędrych, Rola banków centralnych $w$ działaniach na rzecz stabilności finansowej, op. cit., s. 14. 


\section{DZIALANIA BANKÓW CENTRALNYCH W RAMACH SIECI BEZPIECZEŃSTWA FINANSOWEGO PAŃSTWA}

Do działań, jakie pełnią banki centralne w sieci bezpieczeństwa finansowego państwa zaliczamy:

- funkcję pożyczkodawcy ostatniej instancji;

- funkcję zapobiegania destabilizacji systemu finansowego (nadzór bankowy);

- dbałość o bezpieczeństwo i sprawność systemu płatniczego;

- prowadzenie polityki informacyjnej.

Koncepcje banku centralnego jako pożyczkodawcy ostatniej instancji po raz pierwszy sformułowali w XIX wieku H. Thomton i W. Bagehot. Widzieli oni potrzebę pełnienia przez bank centralny tej funkcji, uzasadniając to realizacjąnastępujących celów:

- ochrony zasobów pieniądza w gospodarce;

- działań zgodnych z długoterminowym celem stabilnego wzrostu podaży pieniądza;

- działań na rzecz stabilności całego systemu bankowego, a nie tylko w celu wsparcia pojedynczych instytucji finansowych;

- ograniczenia skali niepewności co do działań władz monetarnych w warunkach kryzysu ${ }^{34}$.

Bank centralny $z$ definicji jest zaangażowany w tworzenie sieci bezpieczeństwa finansowego państwa, ponieważ tradycyjnie pełni rolę pożyczkodawcy ostatniej szansy przez co dostarcza płynności instytucjom, w których jest ona zagrożona. Banki komercyjne finansują swoją działalność przede wszystkim z depozytów gospodarstw domowych i przedsiębiorstw. Pozyskują też częśc środków z od innych banków na rynku międzybankowym. Może jednak wystapić sytuacja, w której instytucje finansowe nie będą ufać sobie nawzajem. Wtedy pozyskanie środków z rynku międzybankowego staje się problemem. Szczególnie uwidoczniło się to zjawisko w przypadku obecnego kryzysu. Bank może mieć również problemy z finansowaniem w momencie znacznego odpływu depozytów. W takiej sytuacji bank komercyjny nie jest w stanie zdobyć gotówki, aby wypłacić depozyty wszystkim oczekującym klientom. Prowadzi to do sytuacji, gdzie banki komercyjne zwracają się o pomoc do banku centralnego. W momencie kiedy bank centralny udostępnia środki finansowe bankom pod zastaw papierów dłużnych jest realizowana funkcja pożyczkodawcy ostatniej instancji ${ }^{35}$. Oczywiście pożyczkodawca ostatniej instancji powinien legitymować się pełną zdolnością do refinansowania banków. Pozwala to na utrzymanie odpowiedniego stopnia płynności sektora bankowego. Pojawienie się niedoboru płynności stwarza zagrożenie dla pojedynczych banków, a w konsekwencji może spowodować niestabilność całego systemu bankowego.

Jak wynika z regulacji Unii Europejskiej, działalność banków centralnych jako instytucji pożyczkodawcy ostatniej instancji jest najsłabszym ogniwem sieci bezpieczeństwa finansowego. W większości krajów unii nie jest ona formalnie przypisana bankom centralnym. Została ona zapisana w ustawie o Banku Szwecji, Narodowym Banku Weegier, Banku Portugalii oraz Memorandum of Understanding na rzecz stabilności Banku Anglii. Jeżeli chodzi o Eu-

34 T. Humphrey, The Lender of Last Resort: The Concept on History, „Economic Review”, March/April 1989. Cyt. za: O. Szczepańska, Funkcja stabilności finansowej w Eurosystemie, „Bank i Kredyt" 2004, nr 6, s. 12.

35 W. Kozioł, Pożyczkodawca ostatniej instancji, „Rzeczpospolita”, 21.01.2011, s. I1. 
ropejski Bank Centralny to nie może on udzielać bezpośredniej pomocy finansowej wspierającej płynność systemów bankowych państw członkowskich. Pomocy takiej może udzielać w stosunku do pojedynczego zagrożonego banku strefy euro. Brakuje również regulacji unijnych dotyczących procedur wspierania płynności banków transgranicznych ${ }^{36}$.

Współcześnie literatura definiuje funkcję pożyczkodawcy ostatniej instancji jako awaryjne wsparcie płynnościowe ${ }^{37}$. Przesłankami decydującymi o tym, że bank centralny powinien pełnić funkcję pożyczkobiorcy ostatniej instancji w sieci bezpieczeństwa finansowego państwa jest asymetria informacji i ryzyko systemowe. Zjawisko asymetrii informacji na rynku finansowym powoduje, że nawet bank wypłacalny może być narażony na masowe wycofanie depozytów lub lokat międzybankowych w czasie kryzysu. Ryzyko systemowe na rynku finansowym polega na tym, że kryzys jednej instytucji finansowej może szybko przenieść się na resztę uczestników rynku i poważnie zakłócić funkcjonowanie całego systemu ${ }^{38}$.

Podstawową i wyróżniającą cechą banku centralnego jako instytucji pożyczkodawcy ostatniej instancji jest szybkość, z jaką bank centralny może zareagować na problem pojedynczego banku, wynikający z utraty płynności. Żadna inna instytucja nie jest w stanie zasilić rachunku banku praktycznie natychmiast i w zasadzie bez maksymalnych limitów co do wysokości kwoty wsparcia ${ }^{39}$.

Awaryjne wsparcie banku centralnego jako pożyczkodawcy ostatniej instancji powinno jednak być uruchomione wówczas, gdy kryzysu nie da się rozwiązać metodami rynkowymi i gdy istnieje ryzyko „zarażenia” kryzysem. W takiej sytuacji kryzys jednej instytucji finansowej przenosi się na innych uczestników rynku, a nawet państwa. W przypadku, gdy mamy do czynienia z zasilaniem płynności banków uznanych za niewypłacalne, to bank centralny co do zasady nie powinien udzielić im wsparcia płynnościowego. Powinien jednak rozważyć jakie wiążą się z tym skutki dla całego sytemu finansowego ${ }^{40}$. Bank centralny, realizując funkcję pożyczkodawcy ostatniej instancji, posiada właściwe instrumenty pozwalające na stabilizację płynności sektora bankowego, a co za tym idzie zapewnienia mu bezpieczeństwa. Do instrumentów tych zaliczamy: system rezerw obowiązkowych, operacje otwartego rynku, operacje kredytowo-depozytowe ${ }^{41}$.

Istotnym instrumentem wsparcia płynnościowego, a co za tym idzie realizacji funkcji pożyczkodawcy ostatniej instancji w czasie kryzysu są porozumienia swapowe ${ }^{42}$. Zostały one utworzone przez System Rezerwy Federalnej w 1962 r. ${ }^{43}$

36 A. Jurkowska-Zeidler, Bezpieczeństwo rynku finansowego w świetle prawa Unii Europejskiej, Warszawa 2008, s. 310 i 356.

37 Dong He, Emergency LiquiditySupport Facilities, IMF Working Paper 2000, WP/00/79, s. 6.

38 O. Szczepańska, P. Sotomska-Krzysztofik, M. Pawliszyn, Banki centralne wobec kryzysów w systemie bankowym, „Materiały i Studia” 2009, z. 179, s. 11, http://www.nbp.pl/publikacje/materialy_i_studia/ms179.pdf (16.08.2012).

$39^{-}$Ibidem, s. 9.

40 A. M. Jurkowska, Bank centralny a bezpieczeństwo i stabilność systemu finansowego, w: Ład instytucjonalny $w$ gospodarce, red. B. Polszakiewicz, J. Boehlke, Toruń 2005, s. 266.

41 A. Nowak-Far, Unia Gospodarcza i Walutowa w Europie, t. XII, Warszawa 2011, s. 132-142.

42 Swap - umowa między dwiema lub więcej stronami obejmująca wymianę przepływów gotówkowych.

43 J. Bogołębska, Rola współpracy banków centralnych w stabilizowaniu międzynarodowego środowiska finansowego. Doświadczenia kryzysu finansowego 2007-2009, w: Od kryzysu do ożywienia. 
Pozytywna ocena efektywności uruchomionych porozumień swapowych w czasie kryzysu sprawiła, że bez współpracy banków centralnych globalna niestabilność finansowa byłaby znacznie większa. Okazuje się, że efektywność porozumień swapowych wynika głównie z szybkości reakcji banków centralnych w dostarczaniu płynności i dużej wartości transferowych funduszy ${ }^{44}$.

Funkcja nadzoru bankowego jest związana z historią banków centralnych. Proces przyznawania bankom centralnym kompetencji nadzoru bankowego przebiegał na dwa sposoby: ewolucyjnie, czyli przez stopniową zmianę ich funkcji i roli w systemie bankowym oraz poprzez decyzje administracyjne rządu.

Z czasem banki centralne otrzymały przywileje wyróżniające ich z innych banków. Działo się tak dlatego, że gromadziły i przechowywały one dochody państwa oraz realizowały jego wydatki, a w zamian rządy przyznawały im przywileje dające przewage nad pozostałymi bankami. Konsekwencją sprawowania przez banki centralne pożyczkodawcy ostatniej instancji było prawo do kontroli nad nimi.

Obecnie biorąc pod uwagę kryterium dotyczące stopnia zaangażowania banku centralnego w nadzór bankowy, można wyróżnić następujące modele organizacji nadzoru:

- nadzór bankowy w banku centralnym;

- nadzór bankowy wydzielony z banku centralnego;

- model pośredni.

Nadzór bankowy w banku centralnym oznacza, że jest on formalnym organem nadzoru bankowego. Takie umiejscowienie nadzoru bankowego oznacza najwyższy stopień zaangażowania banku centralnego w nadzór nad bankami. W tym modelu bank centralny posiada pełny dostęp do informacji o bankach i dysponuje wszystkimi instrumentami nadzorczymi. Model, w którym bank centralny sprawuje nadzór nad systemem bankowym jest rozwiązaniem powszechnie stosowanym na świecie. Na uwagę zasługują rozwiązania w Holandii, Czechach i Słowacji, gdzie integracja nad całym sektorem finansowym jest umieszczona w strukturach banku centralnego. Oznacza to poszerzenie kompetencji nadzorczych banku centralnego o inne sektory systemu finansowego ${ }^{45}$.

Działania nadzorcze odgrywają bardzo istotną rolę w zapewnieniu bezpieczeństwa finansowego. Bezpośrednie kompetencje nadzorcze nad instytucjami finansowymi ma Rezerwa Federalna. Są to bardzo szerokie kompetencje. Niespotykane dotychczas kompetencje wprowadziła ustawa Dodd-Frank Wall Street Reform and Consumer Protection Act z 21 lipca 2010 r. Ustawa ta poszerza kompetencje nadzorcze Fed na inne firmy, których upadek mógłby stanowić zagrożenie dla stabilności sektora finansowego. Są to firmy o znaczeniu systemowym, wskazane przez Radę ds. Nadzorowania Stabilności Finansowej ${ }^{46}$.

Dylematy wspótczesnej polityki finansowej, red. J. L. Bednarczyk, W. Przybylska-Kapuścińska, Warszawa 2011, s. 50.

44 Ibidem, s. 58.

45 O. Szczepańska, Stabilność finansowa jako cel banku centralnego. Studium teoretyczno-porównawcze, op. cit., s. 157-158.

46 A. Matysek-Jędrych, Rola banków centralnych w działaniach na rzecz stabilności finansowej, op. cit., s. 18. 
Umiejscowienie nadzoru poza bankiem centralnym oznacza, że w państwie funkcjonuje odrębna instytucja nadzoru finansowego lub nadzoru bankowego, a bank centralny nie ma żadnych kompetencji kontroli nad bankami. W takim przypadku wszelkie informacje może uzyskać od odrębnej instytucji nadzorczej. Ustawodawcy dbają, aby w krajach, gdzie funkcjonuje odrębna instytucja nadzoru finansowego zostały stworzone odpowiednie warunki do współpracy i wymiany informacji instytucji nadzoru z bankiem centralnym. Polegają one na operacyjnym zaangażowaniu banku centralnego w wykonywanie czynności nadzorczych, takich jak prowadzenie inspekcji bankowych „,na miejscu” lub analiz „,zza biurka”. Chodzi również o wspólne zasoby banku centralnego i instytucji nadzorczej, najczęściej wspólne bazy danych, personel, obsługa techniczna, IT; współudział banku centralnego we władzach instytucji nadzorczej lub wpływ banku centralnego na obsadę stanowisk we władzach nadzoru, a także o podpisywanie specjalnych porozumień na temat wymiany informacji i współpracy na rzecz stabilności finansowej ${ }^{47}$.

Model pośredni polega na tym, że bank centralny nie jest formalnym organem nadzoru, a w kraju istnieją inne instytucje odpowiedzialne za nadzór bankowy. Jednak w praktyce banki centralne mają dostęp do informacji i w różnym stopniu angażują się w bieżące sprawowanie nadzoru. Przykładem zastosowania pośredniego modelu nadzoru była Polska (do 2008 r.), Francja, Niemcy i Austria ${ }^{48}$. W Niemczech bank centralny wykonuje określone zadania nadzorcze, ale formalnym organem kontroli jest wyspecjalizowana instytucja. Na podstawie ustawy z 22 kwietnia 2002 r. o utworzeniu federalnej instytucji sprawującej zintegrowany nadzór nad usługami finansowymi powstał nowy urząd Federalna Finansowa Władza Nadzorcza (tzw. BaFin). W odniesieniu do funkcji nadzoru bankowego ustawa zobowiązuje BaFin do współpracy z Federalnym Bankiem Niemiec (DB). Polega ona na sprawowaniu bieżącego nadzoru nad wszystkimi instytucjami prowadzącymi operacje bankowe. Dokonuje się tego na drodze badania sprawozdań banków oraz kontroli „na miejscu”. Istotnym elementem tej współpracy jest również konsultowanie przepisów i regulacji wpływających na zachowania banków wydawanych przez BaFin z bankiem centralnym Niemiec. Jednocześnie DB jest zobowiązany do bieżącego informowania BaFin o istotniejszych decyzjach oraz ważniejszych faktach mających miejsce w działalności banków ${ }^{49}$.

Sprawny system płatniczy to warunek prawidłowego przebiegu wszelkich operacji gospodarczych. Obecnie gospodarka jest uzależniona od szybkiego, taniego i bezpiecznego przesyłania środków pieniężnych. Instytucją, która działa w ramach sieci bezpieczeństwa finansowego i jest odpowiedzialna za prawidłowe funkcjonowanie systemu płatniczego jest bank centralny.

Skuteczne kontrolowanie przez banki centralne systemów płatniczych wymaga ich systematycznego kontrolowania. W związku z tym banki muszą korzystać z szeregu informacji o funkcjonowaniu systemu. Istotne jest zatem prawne zagwarantowanie bankom centralnym dostęp do tych informacji. Bank Anglii, Bank Japonii czy Narodowy

47 O. Szczepańska, Stabilność finansowa jako cel banku centralnego. Studium teoretyczno-porównawcze, op. cit., s. 161-162.

48 Ibidem, s. 158-159.

49 W. Baka, Bankowość europejska, Warszawa 2005, s. 161-162. 
Bank Polski nie są prawnie uprawnione do gromadzenia informacji o funkcjonowaniu systemów płatniczych. Konsekwencją przeprowadzonych kontroli jest możliwość wpływu przez bank centralny na uczestników systemów płatniczych. Takie gwarancje prawne mają Bank Kanady, Bank Szwajcarii i Europejski Bank Centralny. W przypadku Narodowego Banku Polskiego i Rezerwy Federalnej prawo to jest ograniczone ${ }^{50}$.

W dziedzinie nadzoru nad systemem płatniczym przez banki centralne zwrócono uwagę na współpracę między nimi. Związana jest ona z przeobrażeniami współczesnego systemu finansowego. W rezultacie bezpieczeństwo funkcjonowania krajowego systemu płatniczego coraz bardziej zależy od działania systemów płatniczych w innych państwach. Wzmacniającą przesłanką tej współpracy w strefie euro są działania integracyjne. Istotne różnice między prowadzonymi działaniami nadzorczymi banków centralnych a stanem prawnym w tym zakresie doprowadzą do dostosowań regulacji, zwiększających uprawnienia banków centralnych w tym względzie. Dąży się również do tego, aby w systemach finansowych państw wysoko rozwiniętych ujednolicić standardy funkcjonowania systemów płatniczych ${ }^{51}$.

Metody, za pomocą których banki centralne posługują się, aby wprowadzić konieczne zmiany w systemie płatniczym mogą być następujące ${ }^{52}$ :

- moralna perswazja to najczęściej wykorzystywany przez banki centralne sposób oddziaływania na system płatniczy. Nieformalne rozmowy z operatorami służą budowaniu atmosfery wspólnego działania na rzecz stabilności systemów płatniczych;

- dobrowolne uzgodnienia i porozumienia między bankiem centralnym a określonym systemem płatności. Powinny one zawierać listę standardów, jakie system powinien spełniać, oraz określać kompetencje banku centralnego w zakresie ich weryfikacji;

- statutowe uprawnienia do egzekwowania decyzji. W takim przypadku prawo reguluje kompetencje nadzorcze banku centralnego w zakresie zbierania informacji, przeprowadzania inspekcji na miejscu, licencjonowania systemów płatności, nakładania kar, przyznawania i uchylania członkostwa w systemie.

Przejrzyste zasady funkcjonowania banków centralnych wymagają stosowania przejrzystych zasad ich funkcjonowania. W państwach, gdzie bank centralny komunikuje się z rynkami lepiej utrzymuje się wskaźnik wzrostu cen na założonym poziomie. Taka sytuacja powoduje, że wszystkie podmioty rynku finansowego powinny mieć dostęp do informacji dotyczących celów działania banku centralnego. Dlatego ogromną rolę odgrywa polityka informacyjna, jaką realizuje bank centralny w ramach sieci bezpieczeństwa finansowego. Informacje, które podaje bank centralny powinny być konkretne i przydatne jego odbiorcom. Funkcja ta pozwala podmiotom na rynku finansowym zidentyfikować ewentualne zagrożenia i odpowiednio wcześnie podjąć kroki związane $\mathrm{z}$ zapewnieniem stabilności finansowej państwa. Komunikacja banku centralnego $\mathrm{z}$ uczestnikami rynku finansowego związana jest $\mathrm{z}$ dążeniem do ograniczenia zjawiska

50 A. Matysek-Jędrych, Rola banków centralnych $w$ działaniach na rzecz stabilności finansowej, op. cit., s. 20-21.

51 Ibidem, s. 21-22.

52 O. Szczepańska, Stabilność finansowa jako cel banku centralnego. Studium teoretyczno-porównawcze, op. cit., s. 147. 
asymetrii informacji i wzbogacenia wiedzy uczestników rynku o zachowania innych podmiotów. Informacje zamieszczone w raportach dostarczają wiedzy podmiotom indywidualnym takim jak gospodarstwa domowe, przedsiębiorstwa o możliwościach oceny zagrożeń i ewentualnej zmiany zachowań. Polityka informacyjna realizowana przez bank centralny pełni również istotną rolę edukacyjną ponieważ stosowane instrumenty finansowe są coraz bardziej skomplikowane.

Banki centralne prowadzą politykę informacyjną przez prezentacje swoich analiz w seriach zeszytów naukowych, artykułach. Przedstawiają je w formie raportów miesięcznych czy przeglądów kwartalnych. W związku z zaangażowaniem się banków centralnych w sieć bezpieczeństwa finansowego państwa rozpoczęły one publikację raportów o stabilności finansowej ${ }^{53}$.

Bank Szwecji jest pionierem wśród banków centralnych, który dostrzegł potrzebę publikowania materiałów, analiz i opracowań na tematy związane ze stabilnością finansową ${ }^{54}$. Opublikował je w 1997 r. w Raporcie o Stabilności Finansowej. W dokumencie tym omówiono sytuację w zakresie stabilności sektora bankowego Szwecji. Od tego momentu publikowane są analizy Banku Szwecji na temat stabilności finansowej szwedzkiego sektora bankowego ${ }^{55}$.

Raport o Stabilności Finansowej odgrywa podstawową rolę zarówno w polityce wspierania stabilności finansowej Banku Szwecji, jak i w jego komunikacji ze światem zewnętrznym. Dokument ma stanowić źródło wiedzy zachęcić do publicznej debaty na tematy związane ze stabilnością finansową, dostarczając politykom, społeczeństwu, mediom, a przede wszystkim uczestnikom rynków finansowych odpowiednich informacji oraz metod stosowanych $\mathrm{w}$ analizach ${ }^{56}$.

Zakres publikowanych przez bank centralny informacji ma jednak pewne granice. Środowisko finansowe nie może wiedzieć o wszystkich przyszłych decyzjach banku centralnego, ponieważ wzmaga to skłonność do działań spekulacyjnych.

Działania Banku Szwecji w zakresie dbałości o stabilność finansową związane są z kryzysem lat dziewięćdziesiątych XX wieku. W momencie, gdy kryzys miał charakter systemowy i objął znaczną część szwedzkich banków, rząd uznał za stosowne zapewnić ogólne gwarancje dla banków. Duże znaczenie dla tych działań miało powszechne poparcie polityczne. Brak takiego poparcia mógł jeszcze bardziej podważyć zaufanie do szwedzkiego systemu bankowego i pogłębienia się kryzysu. Wspierając ogólny konsensus w tej sprawie, rząd zobowiązał się do ujawnienia opozycji wszelkich informacji dotyczących podejmowanych działań w zakresie wspierania banków. W Szwecji udało się oprzeć chęci ukrywania rzeczywistych rozmiarów występujących problemów. Dokonano tego przez otwarte prezentowanie na wczesnym etapie rozwoju sytuacji wszystkich oczekiwanych strat. Informowano społeczeństwo, krajowy i zagraniczny rynek finansowy. Społeczeństwo przyjęło pozytywnie zastosowaną politykę Banku

\footnotetext{
53 O. Szczepańska, Stabilność finansowa jako cel banku centralnego. Studium teoretyczno-porównawcze, op. cit., s. 180-181.

${ }_{55}$ Jako pierwszy Raport o Stabilności Finansowej przedstawił Bank Anglii w 1996 r.

55 P. Sotomska-Krzysztofik, Jak Bank Szwecji wspiera stabilność finansowa za pomoca polityki informacyjnej, „Bank i Kredyt” 2005, nr 1, s. 17.

56 Ibidem, s. 18
} 
Szwecji i nie było poważnej utraty zaufania do systemu bankowego w całym okresie trwania kryzysu ${ }^{57}$.

Narodowy Bank Polski, prowadząc politykę informacyjną, publikuje roczny raport o stabilności systemu finansowego, a także roczny raport Rozwój systemu finansowego w Polsce, półroczny raport Przeglad stabilności systemu finansowego. Trzy razy w roku publikowana jest projekcja inflacji i PKB. Narodowy Bank Polski opracowuje i upublicznia statystyki dotyczące sektora bankowego. Są one publikowane w Dziennikach Urzędowych NBP, Monitorze Polskim. Przełomem w polityce informacyjnej banku stało się wprowadzenie Internetu. Dzięki niemu mamy natychmiastowy przekaz informacji do nieograniczonej liczby odbiorców ze strony NBP. W politykę informacyjną włączona jest również Rada Polityki Pieniężnej za pośrednictwem, której Narodowy Bank Polski kontaktuje się z otoczeniem. Rada Polityki Pieniężnej publikuje założenia polityki pieniężnej, sprawozdania z wykonania założeń polityki pieniężnej, kwartalne raporty o inflacji, średnioterminowe strategie polityki pieniężnej oraz opinie do projektu ustawy budżetowej. Ponadto Rada Polityki Pieniężnej przygotowuje komunikaty i konferencje prasowe po comiesięcznych obradach.

Najnowszym kanałem informacyjnym banku centralnego są, publikowane w niektórych państwach, np. w Norwegii czy Szwecji, tzw. ,ścieżki przyszłych stóp procentowych". Takie postępowanie sugeruje również Zarząd NBP Radzie Polityki Pieniężnej, domagając się dyskusji o celowości wprowadzenia takiego kanału w Polsce ${ }^{58}$.

Europejski Bank Centralny w ramach realizacji polityki pieniężnej, przekazuje uczestnikom rynku finansowego bieżące informacje. Pozwala to na utrzymanie wzrostu cen w założonych granicach. Bank centralny strefy euro przywiązuje dużą wagę do tego, aby informacje przekazywane były odbiorcom w czasie rzeczywistym. Przekazywanie informacji przez banki centralne powinny być również otwarte, jednoznaczne i przejrzyste, co sprzyja zrozumieniu przez społeczeństwo jak wygląda prowadzenie polityki pieniężnej. Do kanałów kontaktowych w ramach polityki informacyjnej Europejski Bank Centralny wykorzystuje organizowane comiesięczne konferencje prasowe organizowane przez Prezesa i Wiceprezesa bezpośrednio po pierwszym w danym miesiącu posiedzeniu Rady Prezesów. W ramach tej konferencji jest czas na zadawanie pytań i odpowiedzi, umożliwia to przedstawienie opinii publicznej aktualnych i bezstronnych wyjaśnień dotyczących decyzji w zakresie polityki pieniężnej. Ważnym kanałem komunikacji stosowanym przez EBC jest Biuletyn Miesięczny w którym przedstawia się kompleksową analizę otoczenia gospodarczego i sytuacji monetarnej. Ponadto Prezes Europejskiego Banku Centralnego cztery razy w roku staje przed Komisją Gospodarczą i Monetarna Parlamentu Europejskiego, wyjaśniając decyzje dotyczące polityki pieniężnej. Posiedzenie Komisji jest otwarte i publikowane na stronach internetowych Parlamentu Europejskiego i EBC. Wywiady i wystapienia członków Zarządu i Rady Prezesów EBC są również ważnym elementem polityki komunikacyjnej ${ }^{59}$.

57 Ibidem, s. 16

58 G. Szustak, Bank centralny jako ogniwo sieci bezpieczeństwa finansowego, w: Sieć bezpieczeństwa finansowego, op. cit., s. 72.

59 Biuletyn miesięczny. 10 rocznica EBC, EBC, s. 50-52, http://www.ecb.int/pub/pdf/other/ 10thanniversaryoftheecbmb200806pl.pdf (22.08.2012). 
W ostatnich latach problematyka stabilizowania systemu finansowego stała się przedmiotem wielu dyskusji w aspekcie teoretycznym i politycznym. Jak wiemy podstawowym celem działalności banku centralnego jest dbałość o stabilny poziom cen. Obecnie podejmuje się działania, aby banki centralne obciążyć jeszcze jednym dodatkowym celem, jakim jest stabilność systemu finansowego. Może to zagrozić skuteczności realizacji podstawowego celu. Sytuacja ta rodzi potrzebę zdefiniowania zakresu działań stabilizacyjnych banku centralnego w aktach prawnych.

Od lat dziewięćdziesiątych XX wieku nastąpiło zwiększenie znaczenia stabilności finansowej w hierarchii celów banków centralnych. Cel ten jest nadal kontynuowany. Może on być realizowany przez udział banku centralnego w sieci bezpieczeństwa finansowego. Powodem dla którego bank centralny angażuje się w działania sieci bezpieczeństwa finansowego jest to, że prawidłowo funkcjonujący i rozwijający się system finansowy korzystnie wpływa na wzrost gospodarczy i dobrobyt społeczny. Powoduje to, że stabilność finansowa traktowana jest jako dobro publiczne. W związku z tym cały system finansowy powinien korzystać ze wsparcia instytucji tworzących sieć bezpieczeństwa finansowego, a w szczególności ze wsparcia banku centralnego. Dbałość banków centralnych o stabilność systemu finansowego w ramach sieci bezpieczeństwa tworzy sprzyjające warunku dla realizacji podstawowego celu, jakim jest stabilność cen.

Działania banku centralnego podejmowane w zakresie stabilności finansowej w ramach sieci bezpieczeństwa finansowego powinny być ukierunkowane przede wszystkim $\mathrm{na}^{60}$ : zapewnienie sprawności i bezpieczeństwa systemów płatniczych, pogłębianie oceny stanu stabilności finansowej na podstawie tzw. analiz makroostrożnościowych, a także na znaczne wykorzystanie i zwiększenie roli polityki informacyjnej dotyczącej czynników i warunków stabilności finansowej. Chodzi również o zachowanie, a nawet zwiększanie roli banku centralnego w sprawowaniu funkcji nadzoru bankowego i szerzej - nadzoru finansowego ${ }^{61}$.

Znaczenie banku centralnego w sieci bezpieczeństwa finansowego wzrasta. Potwierdzeniem tej tendencji jest fakt, że Europejski Bank Centralny przywiązuje duże znaczenie do angażowania się $\mathrm{w}$ zapewnienie stabilności finansowej.

Bank centralny $w$ ramach sieci bezpieczeństwa finansowego państwa powinien pełnić aktywną rolę wiodąca. Może on znacząco wpływać na to co się dzieje na rynku zarówno, gdy brak zagrożenia kryzysem, jak i w czasie jego przebiegu. Nie jest możliwe, aby bank centralny funkcjonował poza siecią bezpieczeństwa finansowego. Bank centralny powinien pełnić kluczową rolę w procesie wymiany informacji w warunkach kryzysowych. Zbytnie zaangażowanie banku centralnego w sieci bezpieczeństwa finansowego państwa niesie za sobą ryzyko nadużycia. Grozi zachęceniem rządów do bezczynności. Wynika to z przeświadczenia, że inni wykonują zadania, które oni uważają za zbyt trudne.

${ }^{60}$ W. Baka, Geneza, funkcje i niezależność banku centralnego, w: Studia z bankowości centralnej i polityki pieniężnej, red. W. Przybylska-Kapuścińska, Warszawa 2009, s. 92.

61 Ibidem. 


\title{
STRESZCZENIE
}

Artykuł poświęcony jest funkcjonowaniu banku centralnego w sieci bezpieczeństwa finansowego państwa. Charakteryzuje pojęcie bezpieczeństwa, bezpieczeństwa finansowego oraz jego cele. Następnie autor prezentuje bank centralny jako główny podmiot sieci bezpieczeństwa finansowego państwa, przedstawiając jego główne działania. Są one przedmiotem rozważań w dalszej części artykułu. Zaliczamy do nich: funkcję pożyczkodawcy ostatniej instancji, funkcję zapobiegania destabilizacji systemu finansowego (nadzór bankowy), dbałość o bezpieczeństwo i sprawność systemu płatniczego, prowadzenie polityki informacyjnej. Autor odwołuje się do doświadczeń EBC, NBP, Banku Szwecji i Federalnego Banku Niemiec związanych z działalnością $w$ ramach sieci bezpieczeństwa finansowego państwa. W zakończeniu autor stwierdza, że bank centralny powinien pełnić aktywną rolę wiodącą w sieci bezpieczeństwa finansowego państwa.

\section{POLICY OF THE CENTRAL BANK AND FINANCIAL SECURITY OF A STATE}

\begin{abstract}
This article concerns functioning of the central bank in the financial safety net of the country. It is characterized by the concept of security, financial security and its objectives. The author then presents the central bank as the main entity of the financial security of the network by presenting its main activities. They are the subject of discussion in the following part of in this article. These include: the function of lender of last resort, the function of preventing destabilizing the financial system (banking supervision), attention to safety and efficiency of the payment system, conducting the information policy. The author refers to the experience of the ECB, the NBP, the Bank of Sweden and the Federal Bank of Germany related to the atcivities of the financial safety net of the country. In conclusion, the author states that the central bank should play an active role in the financial safety net of the country.
\end{abstract}

